\title{
Experimental asbestosis: an investigation of functional and pathological disturbances. II. Results for chrysotile and amosite exposures*
}

\author{
D. M. HIETT $\dagger$
}

From the Department of Occupational Health, University of Manchester, Stopford Building, Oxford Road, Manchester M13 9PT.

ABSTRACT Long-term studies of respiratory function and lung morphology were carried out on control groups of guinea pigs and matched groups exposed by inhalation to asbestos dust. Animals were exposed to aerosols of chrysotile or amosite asbestos containing large numbers of short fibres, for either 9 or 18 days. Resistance and dynamic compliance of the guinea pig respiratory system were measured non-destructively, while the point counting technique was applied to the histological preparations. Under these exposure conditions the extent of pathological and functional changes were not related to differences in duration of exposure. Such changes were more marked, however, in animals exposed at eight rather than three months of age. The measurement of dynamic compliance provided the most sensitive assessment of the functional disturbances, which were more extensive following chrysotile exposure. Progressive peribronchiolar fibrosis developed about 40 weeks after chrysotile exposure at eight months of age, but not until about 70 weeks for animals exposed when three months old. No fibrotic reaction was seen during the 70 weeks of the amosite experiments. The relationships between pathological and functional changes throughout these experiments are discussed, and explanations for the apparent differences in fibrogenicity between chrysotile and amosite are suggested. Early detection of asbestosis may be aided by use of lung function tests known to be sensitive to small airways disease.

\section{Methods}

The experimental methods and the maintenance of animals were described in Part I (British Journal of Industrial Medicine, 1978, 35, 129-134). Each experiment was started with a group of male guinea pigs of the same strain and the same age. Animals were exposed to either chrysotile or amosite aerosols. The exposure equipment (Holt et al., 1964) is at Reading University and the animals made the return journey from the experimental laboratory at Manchester University by train. The animals to be exposed were selected at Reading University at random as regards the results of the preliminary tests of respiratory function. The remaining animals in

\footnotetext{
*This paper is based on part of work accepted as a PhD thesis by the University of Manchester, 1973.

†Present address: The National Occupational Hygiene Service Ltd., 12 Brook Road, Fallowfield, Manchester M14 6UH.

Received for publication 23 March 1976

Accepted for publication 12 October 1977
} 


\section{Results}

\section{RESPIRATORY FUNCTION}

\section{Chrysotile exposure}

There was no significant difference between the respiratory function of experimental and control groups before exposure. The results of these preliminary measurements are given in Table 2 . Changes in respiratory function at a particular time after exposure can conveniently be expressed as the percentage difference from the control value at that time. This provides a standardised form for the results and permits direct comparisons to be made between experiments. The results of respiratory function tests for the three experiments were treated in this way for the period up to 45 weeks from the start of exposure. When plotted, the results indicated that straight line analysis could be applied, and regression lines were fitted using the full individual results. The equations of these regression lines and the number of observations in each analysis are given in Table 3 . As an example the regression lines for compliance changes are shown in Figure 1, but for clarity only the mean values for each measurement interval were plotted. Severe disturbances of respiratory function were detected by the first tests after exposure but recovery towards control values occurred in most cases during the subsequent period up to 45 weeks.

Resistance changes for the two younger groups exposed at 3 months $(\mathrm{Cl}$ and $\mathrm{C} 2$ ), were very similar, with an increased resistance being found immediately after exposure. Both groups showed subsequent recovery towards control values, but the slopes of regression lines fitted to these results were not significantly different from zero (Table 3 ). The slopes were not significantly different from each other (Table 4), thus permitting the calculation of a common slope and parallel regression lines. Analysis of covariance indicated that the vertical displacement of the parallel lines was not significant (Table 5); however, impairment was slightly greater for the 9-day (C1) rather than the 18-day (C2) exposure group. This was also shown by calculating the $95 \%$ confidence limits for each regression line, showing that resistance was significantly increased above the standardised control value until about 22 weeks for the $\mathrm{C} 2$ group and until about 32 weeks for the $\mathrm{C} 1$ group. Regression analysis for the older group, C3, exposed at 8 months of age, showed a different result where resistance tended to increase during the experiment, but again the regression slope was not significantly different from zero (Table 3). This regression slope

Table 1 Summary of experiments

\begin{tabular}{|c|c|c|c|c|c|c|c|}
\hline $\begin{array}{l}\text { Type of asbestos inhaled } \\
\text { and experiment code }\end{array}$ & $\begin{array}{l}\text { Duration of } \\
\text { exposure } \\
\text { (days) }\end{array}$ & $\begin{array}{l}\text { Age at time of } \\
\text { exposure } \\
\text { (months) }\end{array}$ & \multicolumn{2}{|c|}{$\begin{array}{l}\text { Number of animals at } \\
\text { time of exposure } \\
\text { Exposed Control }\end{array}$} & $\begin{array}{l}\text { Duration of } \\
\text { experiment } \\
\text { (weeks) }\end{array}$ & \multicolumn{2}{|c|}{$\begin{array}{l}\text { Number of animals at end of } \\
\text { experiment }\end{array}$} \\
\hline Chrysotile (C1) & 9 & 3 & 44 & 16 & 100 & 15 & 5 \\
\hline Chrysotile (C2) & 18 & 3 & 16 & 14 & 40 & 8 & 6 \\
\hline Chrysotile (C3) & 18 & 8 & 10 & 10 & 45 & 4 & 6 \\
\hline Amosite (A1) & 9 & 8 & 12 & 10 & 70 & 4 & 5 \\
\hline Amosite (A2) & 18 & 3 & 18 & 8 & 70 & 6 & 5 \\
\hline
\end{tabular}

Table 2 Respiratory function before exposure, in control and test animals

\begin{tabular}{|c|c|c|c|c|c|c|c|c|}
\hline $\begin{array}{l}\text { Experiment } \\
\text { code }\end{array}$ & $\begin{array}{l}\text { Respiratory function } \\
\text { test* }\end{array}$ & $\begin{array}{l}\text { Group to act as controls } \\
(\text { mean } \pm S D)\end{array}$ & $n$ & $\begin{array}{l}\text { Group to be exposed } \\
(\text { mean } \pm S D)\end{array}$ & $n$ & Com & $\begin{array}{l}\text { n be } \\
d f\end{array}$ & $\begin{array}{l}\text { nean values } \\
P\end{array}$ \\
\hline $\mathrm{C} 1$ & $\begin{array}{l}\text { Resistance } \\
\text { Compliance } \\
\text { Tidal volume } \\
\text { Breathing rate }\end{array}$ & $\begin{array}{l}0.64 \pm 0.057 \\
0.16 \pm 0.031 \\
2.7 \pm 0.34 \\
78 \pm 30\end{array}$ & $\begin{array}{l}8 \\
9 \\
9 \\
9\end{array}$ & $\begin{array}{l}0.67 \pm 0.068 \\
0.17 \pm 0.035 \\
2.8 \pm 0.53 \\
85 \pm 6.3\end{array}$ & $\begin{array}{l}25 \\
24 \\
25 \\
25\end{array}$ & $\begin{array}{l}1 \cdot 02 \\
0 \cdot 33 \\
0 \cdot 38 \\
0 \cdot 64\end{array}$ & $\begin{array}{l}31 \\
31 \\
32 \\
32\end{array}$ & $\begin{array}{l}\text { NS } \\
\text { NS } \\
\text { NS } \\
\text { NS }\end{array}$ \\
\hline $\mathrm{C} 2$ & $\begin{array}{l}\text { Resistance } \\
\text { Compliance } \\
\text { Tidal volume } \\
\text { Breathing rate }\end{array}$ & $\begin{array}{c}0.26 \pm 0.037 \\
0.19 \pm 0.034 \\
2.4 \pm 0.52 \\
61 \pm 9\end{array}$ & $\begin{array}{l}14 \\
14 \\
14 \\
14\end{array}$ & $\begin{array}{l}0.28 \pm 0.067 \\
0.19 \pm 0.031 \\
2.5 \pm 0.43 \\
65 \pm 10\end{array}$ & $\begin{array}{l}15 \\
16 \\
16 \\
16\end{array}$ & $\begin{array}{l}0.83 \\
0.09 \\
0 \cdot 12 \\
1 \cdot 15\end{array}$ & $\begin{array}{l}27 \\
28 \\
28 \\
28\end{array}$ & $\begin{array}{l}\text { NS } \\
\text { NS } \\
\text { NS } \\
\text { NS }\end{array}$ \\
\hline C3 & $\begin{array}{l}\text { Resistance } \\
\text { Compliance } \\
\text { Tidal volume } \\
\text { Breathing rate }\end{array}$ & $\begin{array}{c}0.23 \pm 0.019 \\
0.24 \pm 0.034 \\
5.0 \pm 0.59 \\
70 \pm 9\end{array}$ & $\begin{array}{r}8 \\
10 \\
10 \\
10\end{array}$ & $\begin{array}{c}0.25 \pm 0.024 \\
0.23 \pm 0.037 \\
5.0 \pm 0.80 \\
76 \pm 13\end{array}$ & $\begin{array}{l}10 \\
10 \\
10 \\
10\end{array}$ & $\begin{array}{l}1.48 \\
0.51 \\
0.03 \\
1.19\end{array}$ & $\begin{array}{l}16 \\
18 \\
18 \\
18\end{array}$ & $\begin{array}{l}\text { NS } \\
\text { NS } \\
\text { NS } \\
\text { NS }\end{array}$ \\
\hline
\end{tabular}

* Resistance in $\mathrm{cmH}_{2} \mathrm{O} / \mathrm{ml} / \mathrm{s}$; compliance in $\mathrm{ml} / \mathrm{cmH}_{2} 0$; tidal volume in $\mathrm{ml}$; breathing rate in breaths/min.

$\mathrm{n}=$ no. of observations; $\mathrm{SD}=$ standard deviation; $\mathrm{NS}=$ not significant; $t=\mathrm{Student}$ 's $t$; df $=$ degrees of freedom; $\mathbf{P}=$ probability, in this and subsequent tables. 
Table 3 Regression analysis of percentage disturbance of respiratory function up to 45 weeks after exposure to chrysotile asbestos

\begin{tabular}{|c|c|c|c|c|c|c|}
\hline Respiratory function test & Experiment code & Regression equations* & $n$ & Comp & $\begin{array}{l}\text { slopes with zero } \\
d f\end{array}$ & $\boldsymbol{P}$ \\
\hline Resistance & $\begin{array}{l}\mathrm{C} 1 \\
\mathrm{C} 2 \\
\mathrm{C} 3\end{array}$ & $\begin{array}{l}y=16-0.39 x \\
y=13-0.37 x \\
y=-2+0.34 x\end{array}$ & $\begin{array}{r}201 \\
92 \\
71\end{array}$ & $\begin{array}{l}1 \cdot 63 \\
0 \cdot 61 \\
1 \cdot 58\end{array}$ & $\begin{array}{r}199 \\
90 \\
69\end{array}$ & $\begin{array}{l}\text { NS } \\
\text { NS } \\
\text { NS }\end{array}$ \\
\hline Compliance & $\begin{array}{l}\text { C1 } \\
\text { C2 } \\
\text { C3 }\end{array}$ & $\begin{array}{l}y=-56+0 \cdot 79 x \\
y=-59+1 \cdot 11 x \\
y=-41+0 \cdot 19 x\end{array}$ & $\begin{array}{r}185 \\
102 \\
71\end{array}$ & $\begin{array}{l}8 \cdot 82 \\
7 \cdot 74 \\
1 \cdot 35\end{array}$ & $\begin{array}{r}183 \\
100 \\
69\end{array}$ & $\begin{array}{l}0 \cdot 001 \\
0 \cdot 001 \\
\text { NS }\end{array}$ \\
\hline Tidal volume & $\begin{array}{l}\mathrm{C} 1 \\
\mathrm{C} 2 \\
\mathrm{C} 3\end{array}$ & $\begin{array}{l}y=-35+0.84 x \\
y=-45+1 \cdot 10 x \\
y=-42+0.50 x\end{array}$ & $\begin{array}{r}185 \\
102 \\
71\end{array}$ & $\begin{array}{l}8 \cdot 70 \\
8 \cdot 01 \\
4 \cdot 25\end{array}$ & $\begin{array}{r}183 \\
100 \\
69\end{array}$ & $\begin{array}{l}0.001 \\
0.001 \\
0.001\end{array}$ \\
\hline Breathing rate & $\begin{array}{l}\mathrm{C} 1 \\
\mathrm{C} 2 \\
\mathrm{C} 3\end{array}$ & $\begin{array}{l}y=56-1.16 x \\
y=50-0.68 x \\
y=95-1.40 x\end{array}$ & $\begin{array}{r}185 \\
102 \\
71\end{array}$ & $\begin{array}{r}10 \cdot 11 \\
2 \cdot 44 \\
3 \cdot 83\end{array}$ & $\begin{array}{r}183 \\
100 \\
69\end{array}$ & $\begin{array}{l}0 \cdot 001 \\
0 \cdot 02 \\
0.001\end{array}$ \\
\hline
\end{tabular}

$* y=\%$ disturbance of respiratory function; $x=$ time in weeks from exposure.

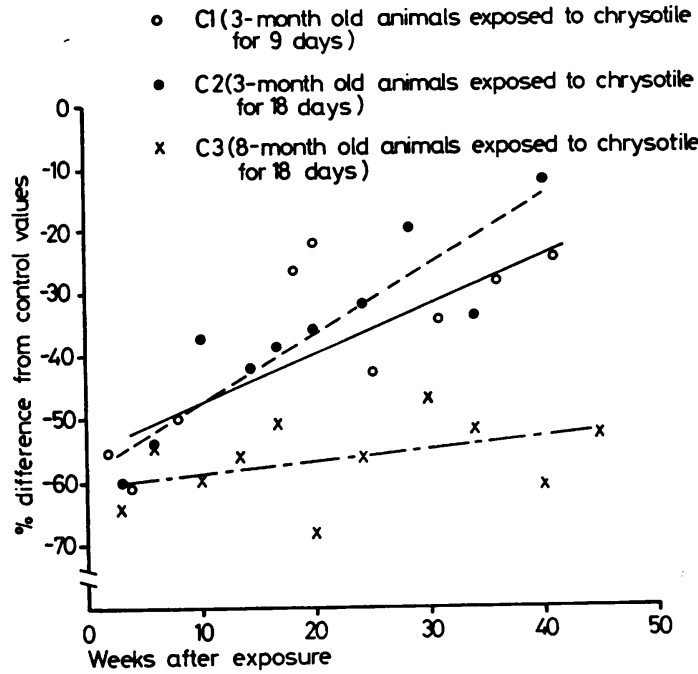

Fig. 1 Percentage difference from control values of compliance, up to 45 weeks after exposure to chrysotile. Regression lines: $\mathrm{C} 1{ }_{-}-$; $\mathrm{C} 2 \_$; 3 3 - - -

was significantly different from that of either of the younger groups, as shown in Table 4 . The $95 \%$ confidence limits of the regression line for the $\mathrm{C} 3$ group indicated that significant increases in resistance occurred after the 17 th week of the experiment.

At first the reductions in compliance were similar for each experiment, falling to less than $50 \%$ of control values (Figure 1). However, subsequent rates of recovery were more marked for the younger groups, $\mathrm{C} 1$ and $\mathrm{C} 2$, than the older one, $\mathrm{C} 3$. The slopes of the regression lines for both the younger groups C1 and C2 were significantly greater than zero (Table 3), indicating a significant recovery towards control values over this period. The slope for the regression line for the older group, C3, showed a slight but non-significant recovery. The regression slopes for both younger groups were significantly greater than for the older group as shown in Table 4. More evidence of a similarity between the two younger groups was seen on comparison of their regression slopes. These were not significantly different (Table 4) and a common slope was calculated. When parallel regression lines were fitted, the impairment of compliance was seen to be slightly more severe for the 9-day, $\mathrm{C1}$, rather than the 18-day, $\mathrm{C} 2$, exposed group. However, analysis of covariance showed that the vertical displacement between the lines was not significant (Table 5). Calculation of the $95 \%$ confidence limits for these regression lines

Table 4 Comparison of recovery rates of respiratory function, measured in terms of regression slope, following chrysotile exposure

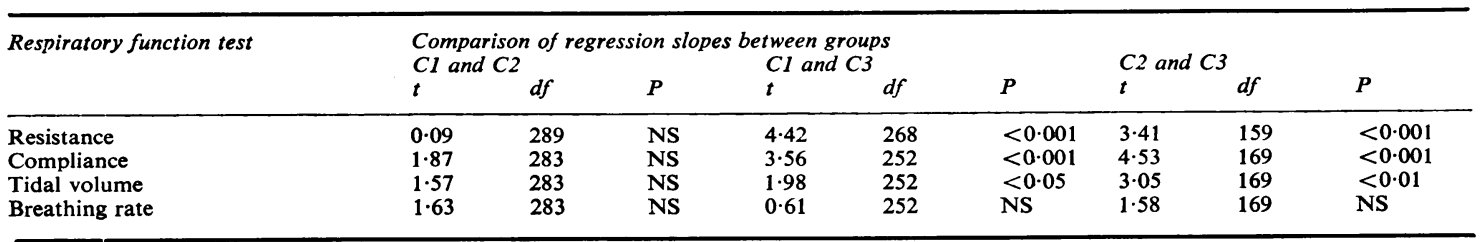


Table 5 Analysis of covariance of the vertical distance between parallel regression lines: chrysotile exposure

\begin{tabular}{|c|c|c|c|c|c|c|}
\hline Respiratory function test & $\begin{array}{l}\text { Experimental groups } \\
\text { compared }\end{array}$ & Equal slope (b) & $\begin{array}{l}\text { Vertical distance between } \\
\text { parallel lines }(d \pm S E)\end{array}$ & $\underset{t}{\text { Signi }}$ & $\begin{array}{l}\text { of } d \\
d f\end{array}$ & $P$ \\
\hline $\begin{array}{l}\text { Resistance } \\
\text { Compliance } \\
\text { Tidal volume } \\
\text { Breathing rate } \\
\text { Breathing rate } \\
\text { Breathing rate }\end{array}$ & 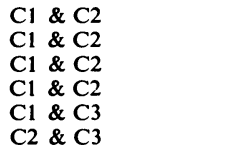 & $\begin{array}{r}-0.38 \\
0.88 \\
0.91 \\
-1 \cdot 03 \\
-1 \cdot 22 \\
-1.01\end{array}$ & $\begin{array}{r}3.45 \pm 2.19 \\
3 \cdot 15 \pm 1.92 \\
5 \cdot 37 \pm 2 \cdot 16 \\
3 \cdot 31 \pm 3 \cdot 22 \\
35 \cdot 22 \pm 3 \cdot 85 \\
32 \cdot 58 \pm 5 \cdot 41\end{array}$ & $\begin{array}{l}1 \cdot 58 \\
1.64 \\
2 \cdot 49 \\
1 \cdot 03 \\
9 \cdot 15 \\
6.02\end{array}$ & $\begin{array}{l}290 \\
284 \\
284 \\
284 \\
253 \\
170\end{array}$ & $\begin{array}{l}\text { NS } \\
\text { NS } \\
<0.02 \\
\text { NS } \\
<0.001 \\
<0.001\end{array}$ \\
\hline
\end{tabular}

demonstrated that the compliance of the three groups remained significantly reduced over the period investigated.

Tidal volume was reduced initially to about $60 \%$ of control values in all three experiments. The subsequent recovery rates for the younger groups, $\mathrm{C} 1$ and $\mathrm{C} 2$, were both significantly greater than zero (Table 3), and their regression slopes were not significantly different from one another (Table 4). Regression lines with common slopes were calculated for these groups and analysis of covariance showed a small but significant vertical displacement between the parallel lines (Table 5). This indicates that the tidal volume of the $\mathrm{C} 2$ group exposed for 18 days was reduced to a significantly greater extent than that of the 9-day exposed group $\mathrm{Cl}$. The recovery rate of the older group, $\mathrm{C} 3$, was significantly less than that of either of the younger groups(Table4) but was significantly greater than zero (Table 3 ). The $95 \%$ confidence limits were calculated for the regression lines, and these indicated that the tidal volume of the older group remained significantly different from control values over the whole experiment. The tidal volumes of the younger groups remained significantly different from control values for the first 35 weeks.

The breathing rates in each experiment were considerably increased immediately after exposure, but significant recovery towards control values occurred thereafter (Table 3). No significant differences were observed between the regression slopes for the three groups (Table 4), but analysis of covariance indicated that the breathing rate of the older group (C3) remained significantly higher than that of either of the younger groups (Table 5). The vertical displacement between parallel regression lines for the younger groups was not significant although the 18-day exposure group (C2) maintained slightly higher breathing rates than did the 9-day exposure group (C1). The $95 \%$ confidence limits of these regression lines indicated that the breathing rates of exposed animals remained significantly higher than control values throughout the experimental period.

The 9-day exposure experiment (C1) was continued for 100 weeks. Over this extended period straight line analysis was not found to be appropriate, but second degree polynomial regression lines were fitted to provide visual indication of the mean overall trends. The curve for the resistance results confirmed the complete recovery to control values at around 40 weeks and indicated that no secondary deterioration occurred within the 100 week period (Figure 2). However, compliance remained at a reduced level throughout the experiment, and a slight tendency towards further deterioration was indicated after 80 weeks. Both tidal volume and breathing rate showed nearly complete recovery by 60 weeks, but again further departure from normal was indicated after about 80 weeks (Figure 3 ).

\section{Amosite exposure}

Disturbances of respiratory function after amosite exposure were considerably less prolonged than those following exposure to chrysotile. Two weeks after exposure the mean compliance of the older, 9-day exposure group (A1) was reduced to less than $50 \%$ of the control value, but considerable recovery was observed at four and eight weeks (Figure 4). Similarly the mean compliance of the younger, 18-day

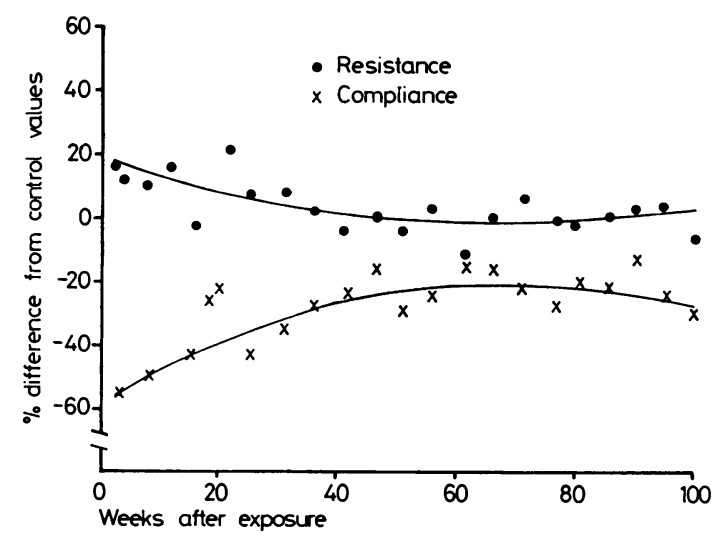

Fig. 2 Percentage difference from control values of resistance and compliance, up to 100 weeks after exposure to chrysotile. 


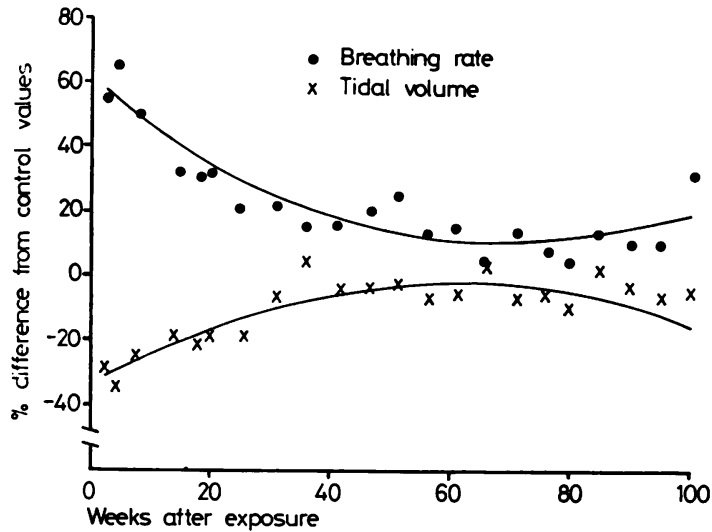

Fig. 3 Percentage difference from control values of tidal volume and breathing rate, up to 100 weeks after chrysotile exposure.

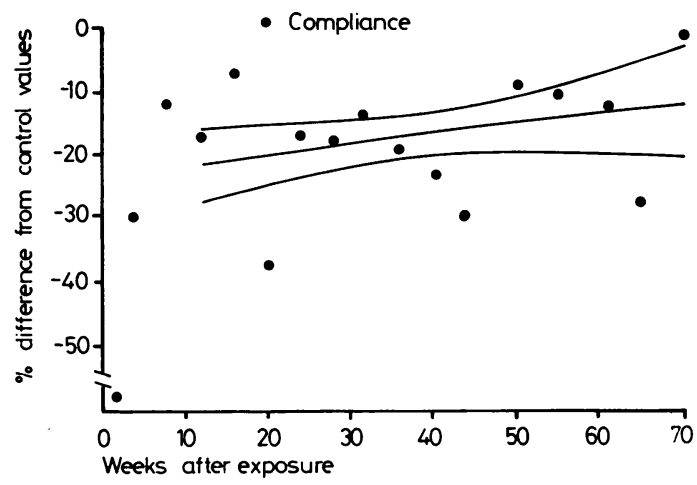

Fig. 4 Regression line and $95 \%$ confidence limits for the percentage difference from control values of compliance, Group Al (Eight-month-old animals exposed to amosite for nine days.)

exposure group (A2) was reduced by nearly $50 \%$ at four weeks with subsequent rapid recovery (Figure 5).

It can be seen from these figures that a secondary, more long-term disturbance of compliance occurred between 12 and 70 weeks. Regression lines were fitted, using the individual results from each experiment and these equations are given in Table 6. The slopes of these lines were not significantly different from zero and the two slopes were not found to be significantly different from each other (Table 7). The vertical distance between the regression lines, when made parallel, was found to be significant (Table 7). This finding indicates that over this period the younger group (A2) remained significantly less affected than the older group (A1) despite the

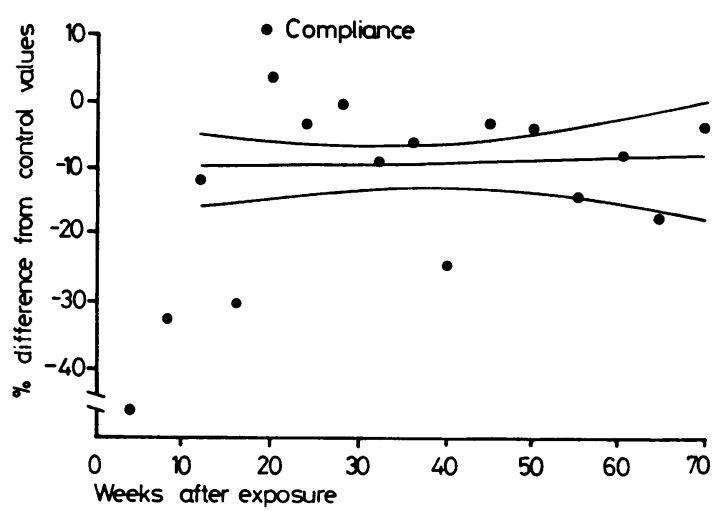

Fig. 5 Regression line and $95 \%$ confidence limits for the percentage difference from control values of compliance, Group A2 (Three-month-old animals exposed to amosite for 18 days).

Table 6 Regression analysis of the percentage disturbance of compliance 12-70 weeks after exposure to amosite

\begin{tabular}{llrlrl}
\hline $\begin{array}{l}\text { Experiment } \\
\text { code }\end{array}$ & $\begin{array}{l}\text { Regression } \\
\text { equations }\end{array}$ & $n$ & \multicolumn{4}{c}{$\begin{array}{c}\text { Comparison of slopes } \\
\text { with zero }\end{array}$} \\
\hline A1 & $\mathrm{y}=-33+0 \cdot 16 \mathrm{x}$ & 95 & $1 \cdot 55$ & 93 & $\mathrm{NS}$ \\
$\mathrm{A} 2$ & $\mathrm{y}=-11+0.036 \mathrm{x}$ & 146 & 0.34 & 144 & $\mathrm{NS}$ \\
\hline
\end{tabular}

$* y=\%$ disturbance of compliance; $x=$ time in weeks from exposure.

longer exposure received by the A2 group. The $95 \%$ confidence limits calculated for both regression lines indicate that the line for the $\mathrm{A} 1$ group remained significantly below the standardised control value over the experimental period (Figure 4), while the line for the A2 group was significantly reduced for the first 67 weeks (Figure 5).

Because the mean resistances of exposed and control groups remained very similar throughout these experiments, the percentage differences were not calculated. Linear regression lines were fitted to the individual results from 2 to 70 weeks. Tidal volumes and breathing rates of the exposed groups were slightly increased immediately after exposure but closely followed the control values for most of each experiment. These results indicated that linear regressions could be fitted to the secondary longterm effect which extended from 10 to 70 weeks. The regression equations for the control and exposed groups are given in Table 8. Only the tidal volume of the A2 group had a slope significantly different from that of its control group. Analysis of covariance was 
applied to those measurements which showed no significant difference between regression slopes of control and exposed groups. The regression lines for the resistance of the exposed groups were slightly above those of the control groups, and this difference was significant for the A2 group. Only small displacements were found for the other measurements and none were significant (Table 9).

\section{HISTOLOGY}

The histological appearances of the lungs of guinea pigs, exposed to chrysotile and amosite dust in the equipment used in the present study, have been described in a well-illustrated paper by Holt $e t$ al. (1966). Our findings were similar to theirs and therefore need only brief description.

Initially the main feature was a granulomatous reaction, mainly peribronchiolar, which resulted in severe structural disruption of the terminal and respiratory bronchioles. In the lungs of animals exposed to chrysotile the severity of this reaction changed little during the first 10 weeks. However, in the animals exposed to amosite the reaction in the lungs had become less uniform at 10 weeks, with some bronchioles showing further damage while others had cleared considerably.

As the amosite experiments continued, further clearance occurred and the granulomatous reaction resolved until, finally, only occasional regions of peribronchiolar thickening were observed. Occasional large focal deposits of dust were formed at subpleural and peribronchiolar sites, but without any apparent collagen formation during the period investigated.

Condensation of the granulomatous reaction with bronchiolar clearance was also seen as the chrysotile

Table 7 Analysis of covariance of the vertical distance between parallel regression lines: percentage reduction of compliance after amosite exposure

\begin{tabular}{|c|c|c|c|c|c|c|c|c|}
\hline \multirow{2}{*}{$\begin{array}{l}\text { Experimental groups } \\
\text { compared }\end{array}$} & \multicolumn{3}{|c|}{ Comparison of separate slopes } & \multirow{2}{*}{$\begin{array}{l}\text { Common } \\
\text { slope }(b)\end{array}$} & \multirow{2}{*}{$\begin{array}{l}\text { Vertical distance between } \\
\text { the parallel regression lines } \\
(d \pm S E)\end{array}$} & \multicolumn{2}{|c|}{ Significance of $d$} & \multirow{2}{*}{$P$} \\
\hline & $t$ & $d f$ & $P$ & & & & & \\
\hline$A 1 \& A 2$ & 0.84 & 237 & NS & 0.086 & $7 \cdot 60 \pm 2.65$ & $2 \cdot 87$ & 238 & $<0.01$ \\
\hline
\end{tabular}

Table 8 Regression analysis of respiratory function of control and exposed groups of animals after exposure to amosite

\begin{tabular}{|c|c|c|c|c|c|c|c|c|}
\hline \multirow[t]{2}{*}{$\begin{array}{l}\text { Respiratory function } \\
\text { test }\end{array}$} & \multirow[t]{2}{*}{$\begin{array}{l}\text { Experiment } \\
\text { code }\end{array}$} & \multirow[t]{2}{*}{$\begin{array}{l}\text { Regression equation } \\
\text { control group } * *\end{array}$} & \multirow[t]{2}{*}{$n$} & \multirow[t]{2}{*}{$\begin{array}{l}\text { Regression equation } \\
\text { exposed group }{ }^{* *}\end{array}$} & \multirow[t]{2}{*}{$n$} & \multirow{2}{*}{\multicolumn{2}{|c|}{$\begin{array}{l}\text { Comparison of slopes } \\
\text { of regression lines } \\
t \quad d f\end{array}$}} & \multirow[b]{2}{*}{$P$} \\
\hline & & & & & & & & \\
\hline $\begin{array}{l}\text { Resistance } \\
\text { ( } 2 \text { to } 70 \text { weeks)* }\end{array}$ & $\begin{array}{l}\text { A1 } \\
\text { A2 }\end{array}$ & $\begin{array}{l}y=0.30-0.00056 x \\
y=0.30-0.00034 x\end{array}$ & $\begin{array}{l}93 \\
84\end{array}$ & $\begin{array}{l}y=0.32-0.00087 x \\
y=0.34-0.00083 x\end{array}$ & $\begin{array}{r}94 \\
138\end{array}$ & $\begin{array}{l}0 \cdot 81 \\
1 \cdot 17\end{array}$ & $\begin{array}{l}183 \\
218\end{array}$ & $\begin{array}{l}\text { NS } \\
\text { NS }\end{array}$ \\
\hline $\begin{array}{l}\text { Tidal volume } \\
\text { (10 to } 70 \text { weeks)* }\end{array}$ & $\begin{array}{l}\text { A1 } \\
\text { A2 }\end{array}$ & $\begin{array}{l}y=4.7-0.014 x \\
y=3.9-0.0068 x\end{array}$ & $\begin{array}{l}84 \\
75\end{array}$ & $\begin{array}{l}y=5.0-0.015 x \\
y=3.5+0.0089 x\end{array}$ & $\begin{array}{r}81 \\
122\end{array}$ & $\begin{array}{l}0 \cdot 16 \\
2 \cdot 29\end{array}$ & $\begin{array}{l}161 \\
193\end{array}$ & $\begin{array}{l}\text { NS } \\
<0.05\end{array}$ \\
\hline $\begin{array}{l}\text { Breathing rate } \\
(10 \text { to } 70 \text { weeks })^{*}\end{array}$ & $\begin{array}{l}\text { A1 } \\
\text { A2 }\end{array}$ & $\begin{array}{l}y=70+0.083 x \\
y=82-0.33 x\end{array}$ & $\begin{array}{l}84 \\
75\end{array}$ & $\begin{array}{l}y=72+0.0054 x \\
y=77-0.13 x\end{array}$ & $\begin{array}{r}81 \\
122\end{array}$ & $\begin{array}{l}0 \cdot 73 \\
1 \cdot 61\end{array}$ & $\begin{array}{l}161 \\
163\end{array}$ & $\begin{array}{l}\text { NS } \\
\text { NS }\end{array}$ \\
\hline
\end{tabular}

${ }^{*}$ period of experiment analysed. $\quad * * y=\%$ disturbance of respiratory function; $x=$ time in weeks from exposure.

Table 9 Analysis of covariance of the vertical distance between parallel regression lines of control and amosite-exposed groups

\begin{tabular}{|c|c|c|c|c|c|c|}
\hline \multicolumn{2}{|c|}{$\begin{array}{l}\text { Respiratory function test } \\
\text { and experiment code }\end{array}$} & \multirow{2}{*}{$\begin{array}{l}\text { Common slope } \\
\begin{array}{l}-7 \cdot 2 \times 10^{-4} \\
-6.3 \times 10^{-4}\end{array}\end{array}$} & \multirow{2}{*}{$\begin{array}{l}\text { Vertical distance between regression lines } \\
(d \pm S E) \\
7 \cdot 5 \times 10^{-3} \pm 7.9 \times 10^{-3 *} \\
1.8 \times 10^{-2} \pm 8.3 \times 10^{-3 *}\end{array}$} & \multicolumn{2}{|c|}{$\begin{array}{l}\text { Significance of } d \\
t \quad d f\end{array}$} & \multirow{2}{*}{ 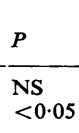 } \\
\hline Resistance & $\begin{array}{l}\text { A1 } \\
\text { A2 }\end{array}$ & & & $\begin{array}{l}0 \cdot 95 \\
2 \cdot 21\end{array}$ & $\begin{array}{l}184 \\
219\end{array}$ & \\
\hline Tidal Volume & A1 & $-1.5 \times 10^{-2}$ & $0 \cdot 21 \pm 0 \cdot 14^{*}$ & $1 \cdot 51$ & 162 & NS \\
\hline Breathing Rate & $\begin{array}{l}\text { A1 } \\
\text { A2 }\end{array}$ & $\begin{array}{l}4.4 \times 10^{-2} \\
-2 \cdot 1 \times 10^{-1}\end{array}$ & $\begin{array}{l}0.30 \pm 1 \cdot 96 \\
1.66 \pm 2 \cdot 30^{*}\end{array}$ & $\begin{array}{l}0 \cdot 15 \\
0 \cdot 72\end{array}$ & $\begin{array}{l}162 \\
194\end{array}$ & $\begin{array}{l}\text { NS } \\
\text { NS }\end{array}$ \\
\hline
\end{tabular}

* regression line for the exposed group vertically displaced above that of the control group. 
experiments proceeded. However, this was later followed by peribronchiolar fibrosis which appeared to progress into the surrounding alveolar regions, where cuboidal metaplasia of the alveolar epithelium resulted in an adenoid appearance. This fibrotic development was evident in the sections obtained at 40 and 45 weeks for the old chrysotile group (C3). Similar fibrosis was observed in sections taken from 70 weeks onwards for the young $(\mathrm{C} 1)$ group. Sections from the young (C2) group showed no fibrotic development during the 40-week experiment.

The percentage by volume of different structures during the chrysotile experiments $\mathrm{C} 1$ and $\mathrm{C} 3$ are given in Tables 10 and 11. This analysis was not extended to the $\mathrm{C} 2$ experiment, in which fewer samples were taken. Inter-animal variation was shown by the changes in percentage by volume occupied by normal alveoli during the $\mathrm{Cl}$ experiment, and a second degree polynomial regression curve was fitted to indicate the general trend. The mean value for the percentage by volume of normal alveoli in control animals was shown in Part I (British Journal of Industrial Medicine, 1978, 35, 129-134) to be 94.4. Thus it can be seen that this component was most affected immediately after exposure, but complete recovery to this value was not observed during the 100-week experiment. The percentage by volume of normal alveoli remained predominantly below 90 for the 45-week duration of the C3 experiment (Table 11).

The percentage by volume of different structures during the amosite experiments is given in Tables 12 and 13. In both these experiments the percentage by volume of normal alveoli was less than $90 \%$ at three

Table 10a Percentage by volume of various structures after a 9-day chrysotile exposure (Cl) (weeks 3-36)

\begin{tabular}{|c|c|c|c|c|c|c|c|c|c|c|}
\hline \multirow[t]{2}{*}{ Structure } & \multicolumn{10}{|c|}{ Percentage by volume at intervals in weeks from start of experiment } \\
\hline & 3 & 5 & 10 & 10 & 14 & 19 & 22 & 24 & 26 & 36 \\
\hline Normal alveoli & $86 \cdot 0$ & $77 \cdot 3$ & $80 \cdot 7$ & $87 \cdot 3$ & $85 \cdot 6$ & $84 \cdot 2$ & $90 \cdot 0$ & $85 \cdot 2$ & $91 \cdot 2$ & $90 \cdot 7$ \\
\hline Small vessels & $2 \cdot 5$ & $3 \cdot 1$ & $2 \cdot 8$ & $1 \cdot 1$ & $2 \cdot 9$ & $3 \cdot 0$ & $3 \cdot 6$ & $2 \cdot 8$ & $2 \cdot \overline{1}$ & 1.9 \\
\hline Large bronchioles & 0.9 & $1 \cdot 3$ & $1 \cdot 4$ & $1 \cdot 4$ & $2 \cdot 8$ & $1 \cdot 9$ & $0 \cdot 3$ & $1 \cdot 8$ & $1 \cdot 8$ & $1 \cdot 2$ \\
\hline Terminal bronchioles & 0 & 0 & 0 & $0 \cdot 1$ & $0 \cdot 2$ & $0 \cdot 1$ & 0 & $0 \cdot 1$ & 0 & 0 \\
\hline Respiratory bronchioles & 0 & 0 & $0 \cdot 2$ & $0 \cdot 2$ & 0 & 0 & 0 & 0 & 0 & 0 \\
\hline Damaged alveoli & $4: 8$ & $12 \cdot 1$ & $8 \cdot \overline{8}$ & $4 \cdot 3$ & $3 \cdot 4$ & $4 \cdot 8$ & $3 \cdot 6$ & $6 \cdot 4$ & $2 \cdot 4$ & $2 \cdot 3$ \\
\hline Obliterated bronchioles & $0 \cdot 2$ & $2 \cdot 6$ & $3 \cdot 5$ & 0.5 & $1 \cdot 1$ & $1 \cdot 0$ & 0.4 & 0.5 & 0.3 & 0 \\
\hline Bronchioles with thickened walls & $5 \cdot 6$ & 3.6 & $2 \cdot 6$ & $5 \cdot 1$ & $4 \cdot 0$ & $5 \cdot 0$ & $2 \cdot 1$ & $3 \cdot 2$ & $2 \cdot 2$ & 3.9 \\
\hline Number of points counted & 1617 & 1431 & 1527 & 1509 & 1404 & 1411 & 1596 & 1484 & 1742 & 1454 \\
\hline
\end{tabular}

Table 10b Percentage by volume of various structures after a 9-day chrysotile exposure (C1) (weeks 46-100)

\begin{tabular}{|c|c|c|c|c|c|c|c|c|c|}
\hline \multirow[t]{2}{*}{ Structure } & \multicolumn{9}{|c|}{ Percentage by volume at intervals in weeks from start of experiment } \\
\hline & 46 & 52 & 59 & 64 & 64 & 71 & 80 & 90 & 100 \\
\hline Normal alveoli & $86 \cdot 2$ & $89 \cdot 6$ & $92 \cdot 8$ & $92 \cdot 4$ & $92 \cdot 6$ & $89 \cdot 2$ & $91 \cdot 8$ & $88 \cdot 3$ & $90 \cdot 0$ \\
\hline Large bronchioles & 1.4 & $1 \cdot 8$ & $1 \cdot 3$ & $1 \cdot 3$ & $1 \cdot 5$ & $1 \cdot 2$ & $1 \cdot 3$ & $2 \cdot 3$ & $1 \cdot 1$ \\
\hline Terminal bronchioles & 0 & 0 & $\mathbf{0}$ & $0 \cdot 1$ & 0 & 0 & 0 & 0 & 0 \\
\hline Respiratory bronchioles & 0 & $\mathbf{0}$ & 0 & 0 & 0 & $\mathbf{0}$ & 0 & 0 & 0 \\
\hline Damaged alveoli & $5 \cdot 4$ & $1 \cdot 3$ & c.4 & $1 \cdot 4$ & 0.9 & $3 \cdot 3$ & $1 \cdot 2$ & $1 \cdot 0$ & $2 \cdot 7$ \\
\hline Bronchioles with thickened walls & $2 \cdot 9$ & $3 \cdot 8$ & $3 \cdot 8$ & $3 \cdot 2$ & $2 \cdot 7$ & $5 \cdot 1$ & $3 \cdot 4$ & $5 \cdot 7$ & $4 \cdot 3$ \\
\hline Number of points counted & 1547 & 1532 & 1604 & 1735 & 1621 & 1341 & 1653 & 1537 & 1694 \\
\hline
\end{tabular}

Table 11 Percentage by volume of various structures after an 18-day chrysotile exposure (C3)

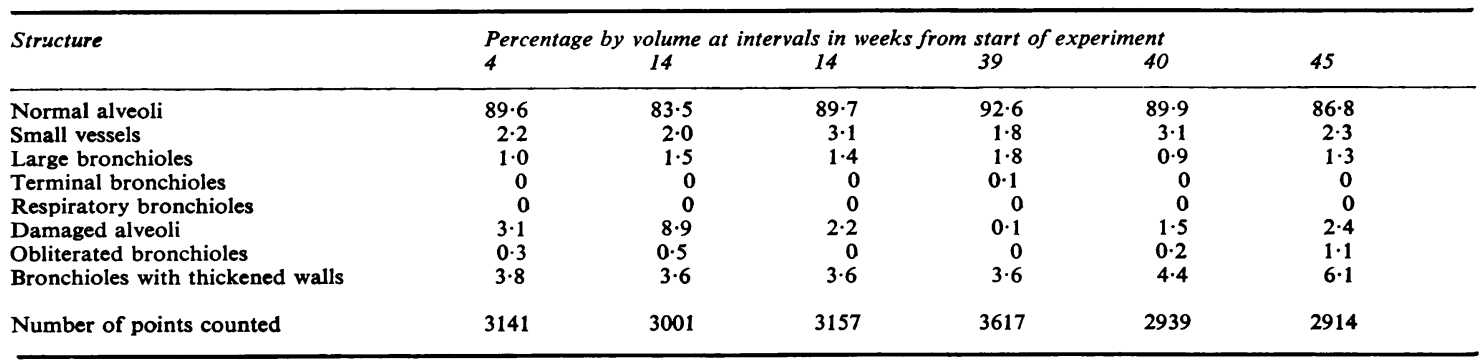


Table 12 Percentage by volume of various structures after a 9-day amosite exposure (AI)

\begin{tabular}{|c|c|c|c|c|c|}
\hline Structure & \multicolumn{5}{|c|}{ Percentage by volume at intervals in weeks from start of experiment } \\
\hline $\begin{array}{l}\text { Normal alveoli } \\
\text { Small vessels } \\
\text { Large bronchioles } \\
\text { Terminal bronchioles } \\
\text { Respiratory bronchioles } \\
\text { Damaged alveoli } \\
\text { Obliterated bronchioles } \\
\text { Bronchioles with thickened walls }\end{array}$ & $\begin{array}{r}88 \cdot 3 \\
1 \cdot 1 \\
1 \cdot 2 \\
0 \\
0 \\
6 \cdot 2 \\
0 \cdot 5 \\
2 \cdot 7\end{array}$ & $\begin{array}{r}83 \cdot 2 \\
2 \cdot 2 \\
1 \cdot 5 \\
0 \\
0 \\
8 \cdot 6 \\
1 \cdot 2 \\
3 \cdot 3\end{array}$ & $\begin{array}{r}89 \cdot 9 \\
2 \cdot 7 \\
0 \cdot 3 \\
0 \\
0 \\
3 \cdot 3 \\
0 \\
3 \cdot 8\end{array}$ & $\begin{array}{r}90 \cdot 5 \\
2 \cdot 3 \\
1 \cdot 3 \\
0 \\
0 \\
2 \cdot 7 \\
0 \\
3 \cdot 2\end{array}$ & $\begin{array}{r}91 \cdot 2 \\
1 \cdot 7 \\
1 \cdot 0 \\
0 \\
0 \\
2 \cdot 4 \\
0 \\
3 \cdot 7\end{array}$ \\
\hline Number of points counted & 2908 & 2986 & 3029 & 3136 & 3265 \\
\hline
\end{tabular}

Table 13 Percentage by volume of various structures after an 18-day amosite exposure (A2)

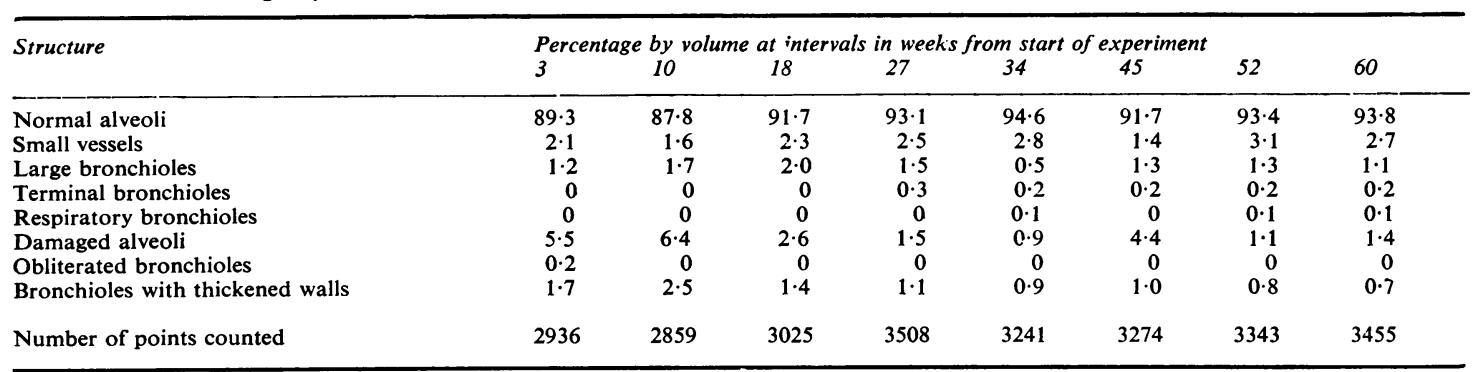

weeks, reducing further at 10 weeks and recovering towards the control value at 18 and 26 weeks. The results indicate that reductions in normal alveolar volume were less severe in the younger group (A2) than the older one (A1) despite the increased exposure of the younger group.

The reduction in the volumes occupied by normal terminal and respiratory bronchioles in these experiments indicates that they were mainly counted under the damaged section. The volume occupied by obliterated bronchioles was rather variable but was in general less than that of the thickened bronchioles. A second degree polynomial was used to indicate the trend in the $\mathrm{C} 1$ experiment, but the results for the $\mathrm{C} 3$ experiment were too few for such analysis. The volume of thickened bronchioles showed a tendency to increase in both experiments when fibrosis was developing. The percentage by volume occupied by thickened bronchioles remained between $3 \%$ and $4 \%$ from 40 to 65 weeks in the old amosite experiment (A1) but the young group (A2) was less severely affected. The percentage volumes occupied by large bronchioles and small blood vessels remained similar to control values throughout these experiments.

\section{Discussion}

The peribronchiolar site of the initial pathological lesion in these experiments corroborates the findings from previous studies of experimental asbestosis (Wagner, 1963; Holt et al., 1966; Gross and de Treville, 1967). Peribronchiolar fibrosis developed in two of the present experiments and was associated with metaplasia of the walls of alveoli adjacent to the damaged bronchioles. Holt et al. (1966) found that those guinea pigs with the greatest fibrotic development also showed the most marked adenoid appearance. Pathological material from early cases of human asbestosis has shown the basic lesion to be peribronchiolar fibrosis (Hourihane and McCaughey, 1966; Gracey et al., 1973), and alveolar metaplasia has also been reported in cases of human asbestosis (Jones Williams, 1957). Thus there may well be a close similarity between the location and mode of development of asbestosis in guinea pigs and man, and in both cases the initial lesion leads to small airways disease.

Hogg et al. (1968) have reported that conventional measures of pulmonary resistance are relatively insensitive to changes in the small airways. The rather small increases in resistance seen in these experiments are compatible with this finding. The period of significant increase in resistance of the $\mathrm{Cl}$ and C2 groups corresponded to the time of maximal bronchiolar disruption. However, inconsistency of this measure was shown by the $\mathrm{C} 3$ group, in which resistance was not significantly 
increased until peribronchiolar fibrosis developed. It is possible that these increases in resistance are related to obstruction in the larger airways, but it was seen that the percentage by volume occupied by large bronchioles remained close to normal throughout.

On the other hand, changes in compliance corresponded well to the quantitative pathological changes. There are two mechanisms by which dynamic compliance can be reduced. First, abnormalities in the elastic properties of the lungs attributable to cellular infiltration and peribronchiolar thickening may lead to changes in true static compliance. Second, it has been suggested that small airways obstruction would also reduce dynamic compliance, especially when measured at high breathing rates (Woolcock et al., 1969). Thus it is probable that the initial large reduction of compliance in each experiment may reflect the severe obstruction of the small airways observed at that time, to an equal if not greater extent than true changes in static compliance.

In both amosite experiments the breathing rate returned to normal levels after 12 weeks, but compliance values remained significantly decreased over an extended period. This may indicate that the measurement was adequately sensitive to detect the changes in true static compliance caused by residual damage to the bronchiolar walls and alveolar parenchyma after the small airways were cleared. The histological disturbances, in terms of abnormalities in the percentage volumes occupied by normal alveoli and bronchioles with thickened walls, were greater in the A1 than the A2 group. This difference was also reflected in the compliance measurements which remained significantly different throughout these experiments, with the A1 group being more severely affected.

In the $\mathrm{Cl}$ experiment the recovery of compliance corresponded both to the observed clearance of the small bronchioles, and to the changes in percentage volume of normal alveoli. The latter component provides an overall estimate of the histological abnormality, as it is reduced both by alveolar and peribronchiolar damage. As fibrosis developed in the later stages of this experiment, compliance tended to decrease and the percentage volume of thickened bronchioles tended to increase. Near-normal breathing rates were maintained from 60 to 80 weeks; the reduced dynamic compliance at this time may therefore primarily reflect impairment of true static compliance.

In the C3 experiment the early development of fibrosis was again accompanied by an increase in the percentage by volume of thickened bronchioles. During this experiment the breathing rate remained significantly increased; therefore, although the prolonged reduction of dynamic compliance may have been partly attributable to the early development of static changes, the obstructive component would also have been emphasised. Thus both the physiological and pathological findings suggest that physiological tests known to be sensitive to small airways obstruction may well be useful in the early detection of asbestosis.

Breathing rates in each experiment were increased during the period of maximum inflammation. Such hyperpnoea may be partly mediated by different impulses from receptors in the lung, such as the 'J' receptors (Paintal, 1969), or 'irritant' receptors (Mills et al., 1970). In addition, compensatory increases in breathing rate may have occurred when reductions in tidal volume were observed.

Comparison of respiratory function of the $\mathrm{C} 1$ and C2 groups indicated that, under the exposure conditions used, differences in exposure duration had little effect on the extent of subsequent changes. It has also been mentioned that a gradient of fibre concentration was observed in the disturbance of respiratory function of animals exposed at different positions within the chamber. It is possible however, that the total deposition of dust deep in the lungs was similar under these various conditions. Immediately after exposure, breathing rates were increased and tidal volumes were reduced. These changes presumably developed during the exposure period, and both tend to reduce deposition within the lung (Muir and Davies, 1967; Dennis, 1971). Timbrell (1970) has shown that penetration of fibres is related to airway diameter, and Sanchis et al. (1971) hold the view that small airways obstruction, as developed during these exposures, reduces alveolar deposition. Thus it is possible that, if abnormalities developed soon after the start of exposure, deposition deep into the lungs became progressively less and the total deposition may be limited to a ceiling value which was reached by animals of all groups within the first nine days of exposure.

Animals exposed when mature, aged eight months, showed greater overall disturbances than those exposed at three months of age. The young A2 group showed significantly less disturbance of compliance than the old A1 group, while the respiratory function of both young groups $\mathrm{C} 1$ and $\mathrm{C} 2$ was significantly less disturbed than that of the old $\mathrm{C} 3$ group. Zaidi et al. (1971) showed that the fibrogenicity of silica was greater in adult dogs than in pups, and although the mechanism behind these findings is not clear, a contributing factor may be the age-related phagocytic activity described by Rasche (1971).

In these experiments chrysotile was found to be more fibrogenic than amosite. This is in contrast to 
the findings of Wagner (1963) and Reeves et al. (1971). However, Timbrell and Skidmore (1968) exposed guinea pigs to an amosite aerosol containing $10 \%$ of fibres longer than $4 \mu \mathrm{m}$, which had a similar fibre distribution to the aerosol used in the present studies $(10 \%$ of fibres longer than $5 \mu \mathrm{m})$. They found histological changes similar to those in this study, with no fibrotic development. These workers also used an amosite aerosol containing $45 \%$ of fibres longer than $4 \mu \mathrm{m}$, but of equal mass concentration as their previous aerosol. Here lesions proved to be progressive and included collagen formation. Thus, differences in the fibre length distributions of aerosols used by various workers may result in discrepancies between findings.

The uptake of amosite dust deep into the lungs of normal and SPF rats has been shown to be three times greater than the uptake of chrysotile dust (Wagner and Skidmore, 1965; Morris et al., 1967) Differential deposition was only minimally involved, as the subsequent clearance rate of chrysotile was some three times faster than that of amosite. Holt et al. (1966) found no chrysotile and only few amphibole fibres in the lymph nodes of exposed guinea pigs, which suggests that clearance occurs mainly via the respiratory tract. LaBelle and Brieger (1959) demonstrated a relationship between the amount of dust cleared and the number of phagocytic cells present in the lungs. Brain (1971) found that some particles are capable of enlisting more macrophages than others; the difference in clearance rates of chrysotile and amosite therefore may be related to their relative abilities to enlist macrophages.

A close relationship has been established between particle cytotoxicity and fibrogenic effect in the lung (Marks and Nagelschmidt, 1959; Conning et al., 1971). Chrysotile has been found to be haemolytic while amosite is only weakly so (Harington et al., 1971). Chrysotile has also been shown to be more cytotoxic to macrophage cultures than amosite (Allison, 1971), and this was especially apparent when freshly ground dusts were used (Robock and Klosterkötter, 1971). Heppleston (1971) suggested that macrophages ingesting cytotoxic particles may release a signal that enlists more macrophages, and indeed Davis (1967) found that many macrophages were attracted to clumps of chrysotile fibres.

As chrysotile fibres appear to be more cytotoxic than amosite fibres, more macrophages may be enlisted for the clearance of chrysotile than of amosite. This may explain the increased clearance rate observed for chrysotile fibres, which could result in chrysotile appearing less fibrogenic than amosite if the clearance pathway via the respiratory tract remains operative. If however this pathway were in some way obstructed, a more severe fibrotic effect would be expected after chrysotile than after amosite exposure. In the present experiments, exposure conditions were such that extensive macrophage infiltration was stimulated by both chrysotile and amosite aerosols, although chrysotile exposure caused the more severe inflammation. The resultant disruption of small airways patency must have caused obstruction of clearance, thus providing a possible explanation for the observed difference in the fibrogenicity of chrysotile over amosite.

In conclusion, this study has shown that the development of experimental asbestosis can be monitored using simple tests of respiratory function, and that these changes can be related to quantitative histological information. The pathological changes observed resemble those described for an early case of asbestosis in man (Gracey et al., 1973), in that the basic lesion was peribronchiolar. Thus, regardless of the type of asbestos inhaled, early detection of asbestosis may be aided by use of respiratory function tests known to be sensitive to small airways disease.

I am indebted to Dr P. F. Holt, Department of Chemistry, University of Reading, for making available his inhalation equipment, and $\mathrm{Dr} S$. Holmes, Health Physics Department, Turner Brothers Asbestos Co. Ltd., Rochdale, for help with the dust sampling. I would like to thank $\mathrm{Dr} \mathrm{H}$. C. Lewinsohn, Turner Brothers Asbestos Co. Ltd., Rochdale, Dr G. Williams, Department of Pathology, University of Manchester and Professor W. R. Lee, Department of Occupational Health, University of Manchester, for their helpful advice, and Mr R. D. Morrisey for his technical assistance. I am grateful to the Asbestosis Research Council for financial support of this work.

\section{References}

Allison, A. C. (1971). Lysosomes and the toxicity of particulate pollutants. Archives of Internal Medicine, 128, 131-139.

Brain, J. D. (1971). The effects of increased particles on the number of alveolar macrophages. In Inhaled Particles III, volum: 1, pp. 209-223. Edited by W. H. Walton. Unwin Brothers: Old Woking, Surrey.

Conning, D. M., Hayes, M. J., Styles, J. A., and Nicholas, J. A. (1971). Comparison between in vitro toxicity of dusts of certain polymers and minerals and their fibrogenicity. In Inhaled Particles III, volume 1, pp. 499-506. Edited by W. H. Walton. Unwin Brothers: Old Woking Surrey.

Davis, J. M. G. (1967). The effects of chrysotile asbestos dust on lung macrophages maintained in organ culture; an electron microscope study. British Journal of Experimental Pathology, 48, 379-385.

Dennis, W. L. (1971). The effect of breathing rate on the deposition of particles in the human respiratory system. In Inhaled Particles III, volume 1, pp. 91-102. Edited 
by W. H. Walton. Unwin Brothers: Old Woking, Surrey.

Gracey, D. R., Divertie, M. B., and Brown, A. L. (1973). The blood-air barrier in pulmonary asbestosis; study of a case by electron microscopy. Chest, 63, 46-51.

Gross, P., and de Treville, R. T. P. (1967). Experimental asbestosis: studies on the progressiveness of the pulmonary fibrosis caused by chrysotile dust. Archives of Environmental Health, 15, 638-649.

Harington, J. S., Miller, K., and MacNab, G. (1971). Hemolysis by asbestos. Environmental Research, 4, 95-117.

Heppleston, A. G. (1971). Observations on the mechanism of silicotic fibrogenesis. In Inhaled Particles III, volume 1, pp. 357-369. Edited by W. H. Walton. Unwin Brothers: Old Woking, Surrey.

Hogg, J. C., Macklem, P. T., and Thurlbeck, W. M. (1968). Site and nature of airway obstruction in chronic obstructive lung disease. The New England Journal of Medicine, 278, $1355-1360$

Holt, P. F, Mills, J., and Young, D. K. (1964). The early effects of chrysotile asbestos dust on the rat lung. Journal of Pathology and Bacteriology, 87, 15-23.

Holt, P. F., Mills, J., and Young, D. K. (1966). Experimental asbestosis in the guinea pig. Journal of Pathology and Bacteriology, 92, 185-195.

Hourihane, D. O'B., and McCaughey, W. T. E. (1966). Pathological aspects of asbestosis. Postgraduate Medical Journal, 42, 613-622.

Jones Williams, W. (1957). Alveolar metaplasia: its relationship to pulmonary fibrosis in industry and the development of lung cancer. British Journal of Cancer, 11, 30-42.

LaBelle, C. W., and Brieger, H. (1959). Synergistic effects of aerosols. Archives of Industrial Health, 20, 100-105.

Marks, J., and Nagelschmidt, G. (1959). Study of the toxicity of dust with use of the in vitro dehydrogenase technique. Archives of Industrial Health, 20, 383-389.

Mills, J. E., Sellick, H., and Widdicombe, J. G. (1970). Epithelial irritant receptors in the lungs. In Breathing: Hering-Breuer Centenary Symposium, pp. 77-92. Edited by Ruth Porter. J. and A. Churchill: London.

Morris, T. G., Roberts, W. H., Silverton, R. E., Skidmore, J. W., Wagner, J. C., and Cook, G. W. (1967). Comparison of dust retention in specific pathogen free and standard rats. In Inhaled Particles and Vapours II, pp. 205-212. Edited by C. N. Davies. Pergamon Press: Oxford.

Muir, D. C. F., and Davies, C. N. (1967). The deposition of $0.5 \mu \mathrm{m}$ diameter aerosols in the lungs of man. Annals of Occupational Hygiene, 10, 161-174.

Paintal, A. S. (1969). Mechanism of stimulation of type J pulmonary receptors. Journal of Physiology, 203, 511-532.

Rasche, B. (1971). Reactions of alveolar macrophages during short-term dust exposure with and without various pharmacological substances. In Inhaled Particles III, volume 1, pp. 391-400. Edited by W. H. Walton. Unwin Brothers: Old Woking, Surrey.

Reeves, A. L., Puro, H. E., Smith, R. G., and Vorwald, A. J. (1971). Experimental asbestos carcinogenesis. Environmental Rescarch, 4, 496-511.

Robock, K., and Klosterkötter, W. (1971). Biological action of different asbestos dusts with special respect to fibre length and semiconductor properties. In Inhaled Particles III, volume 1, pp. 465-474. Edited by W. H. Walton. Unwin Brothers: Old Woking, Surrey.

Sanchis, J., Dolovich, M., Chalmers, R., and Newhouse, M. T. (1971). Regional distribution and lung clearance mechanisms in smokers and non-smokers. In Inhaled Particles III, volume 1, pp. 183-188. Edited by W. H. Walton. Unwin Brothers: Old Woking, Surrey.

Timbrell, V. (1970). The inhalation of fibres. In Pneumoconiosis, Proceedings of the International Conference, Johannesburg, pp. 3-9. Edited by H. A. Shapiro. Oxford University Press: London.

Timbrell, V., and Skidmore, J. W. (1968). Significance of fibre length in experimental asbestosis. In Biologische Wirkungen des Asbestes, Internationale Konferenz, Dresden (Deutsches Zentralinstitut für arbeitsmedizin, Berlin, Gesellschaft für arbeitshygiene und arbeitsshutz in der $D D R$ ), pp. 52-56. Edited by E. Holstein, Dresden.

Wagner, J. C. (1963). Asbestosis in experimental animals. British Journal of Industrial Medicine, 20, 1-12.

Wagner, J. C., and Skidmore, J. W. (1965). Asbestos dust deposition and retention in rats. Annals of the New York Academy of Sciences, 132, 77-86.

Woolcock, A. J., Vincent, N. J., and Macklem. P. T. (1969). Frequency dependence of compliance as a test for obstruction in small airways. Journal of Clinical Investigation, 48, 1097-1106.

Zaidi, S. H., Shanker, R., and Dogra, R. K. S. (1971). Experimental studies on early stages of the development of pulmonary silicosis in pups. Environmental Research, 4, 243-252. 